\title{
Proceeding
}

9th INSHS International Christmas Sport Scientific Conference, 4-6 December 2014. International Network of Sport and Health

Science. Szombathely, Hungary

\section{Differences skills praxic in developmental age}

\author{
DEBORA DI IORIO $\triangle$, FILIPPO GOMEZ PALOMA \\ Department of Human, Philosophical and Education Science, University of Salerno, Italy
}

\begin{abstract}
Di lorio, D., \& Gomez, F. (2015). Differences skills praxic in developmental age. J. Hum. Sport Exerc., 9(Proc1), pp.S430-S436. Intelligence could be understood as a system of active operations, which involves a functional continuity between the higher forms of thought and cognitive-motor adaptation to social and physical environment surrounding the subject. (Piaget, 1998) Gardner says that his multiple intelligences, especially that bodily-kinesthetic, develop when the subject is in contact with the outside world, lived experiences and assimilates information. (Gardner, 1988) With this study we would like to underline as it does the development of skills praxic and its evolution over the age of development. 77 students participated in the research, from I to $\mathrm{V}$ elementary, to which was administered, individually, a battery of tests. The tests were acquired by the Special Organization of Florence and treated by Rossana De Beni, Gruppo MT, "Q1 elementary": tests for the compilation of initial profile of the new evaluation document. Initial results may prove as there could be a correlation between the age child's cognitive and its ability to perform movements conscious and coordinated; capacity which, according to the data, you can reach to the last years of primary school. The correct motor development, the acquisition of skills praxic and the awareness of their motor pattern, allow the passage from the body as a tool, the own body, through an increasingly refined control of his movements. The praxis, therefore, are acquired through experience and a learning process that allows to establish an intentional relationship between motor, intellectual and emotional phenomena (Le Boulch, 2006). Key words: INTELLIGENCE, MOTOR SKILLS, BODY, MOVEMENT.
\end{abstract}

\footnotetext{
Corresponding author. University La Sabana, Puente Del Comun, Chia, Cundinamarca, Colombia

E-mail: diiorio_debora@libero.it

9th INSHS International Christmas Sport Scientific Conference, 4-6 December 2014. International Network of Sport and

Health Science. Szombathely, Hungary.

JOURNAL OF HUMAN SPORT \& EXERCISE ISSN 1988-5202

(c) Faculty of Education. University of Alicante

doi:10.14198/jhse.2015.10.Proc1.36
} 


\section{INTRODUCTION}

Any explanation you want to give to the concept of intelligence, this is always based even on neurobiological studies. Neurobiology comprises mental processes only putting them in correspondence with the organism, from which they originated elementary cognitive functions, without ever being able to explain the higher laws that impose themselves on the mind (Gomez Paloma F., Rio L., D'Anna C. 2014). Hence the need to connect the intelligence to psychological studies (Altavilla G., Tafuri D., Raiola, G., 2014).

Intelligence could be understood as a system of active operations, which involves a functional continuity between the higher forms of thought and cognitive-motor adaptation to social and physical environment surrounding the subject (Raiola G., Tafuri D., Gomez Paloma F., 2014).

The adaptation, then, the interaction with the environment, arises from the need of the individual to be in equilibrium with the outside world and to control it, assimilating all the information that modify existing mental patterns, by creating new ones. (Piaget, J., 1998)

The intelligence is built at a time when there is the contact with the environment; in this regard, Gardner says that his multiple intelligences, especially that bodily-kinesthetic, develop when the subject is in contact with the outside world, lived experiences, assimilates information and feel emotions. (Gardner, H., 1988).

The correct motor development, the acquisition of skills praxic and the awareness of their motor pattern, allow the passage from the body as a tool, the own body, through an increasingly refined control of his movements. The praxis, therefore, are acquired through experience and a learning process that allows to establish an intentional relationship between motor, intellectual and emotional phenomena. (Le Boulch, J., 2006)

In this regard, you might investigate the different skill development praxic in developmental age, considering 77 students of infancy and primary.

\section{MATERIAL AND METHODS}

The research, exploratory character, aims to investigate the acquisition of praxis and their own body image; Specifically, this research seeks to understand how and at what age development occurs bodily-kinesthetic intelligence and motor skills.

\section{Participants}

77 students of the Institute Comprehensive "Padre Pio", the elementary school of the City of Pietrelcina (Bn) participated in the research.

The choice of these participants is dictated by the desire to have an idea complete and satisfactory development praxic of these skills in children of primary school and lower secondary, from the first to the last years of schooling.

The battery of tests, which have been subjected the students, is relatively complex and heterogeneous, but appropriate for the age of the students, of all levels. 


\section{Procedures}

The tests are all individual and have been administered in classrooms for the duration of 60 minutes. The tests I, II and III elementary are equal, but differ from those of IV and V.

The tests I, II, and III allow to analyze the motor area, the children, with implementation of imitative praxis: the test consists of a series of items that explore the one hand the level of motor skill reached, on the other, transition from simple motor coordinations to more complex motor actions that require interiorization of the body schema. Children are invited to imitate facial expressions and limbs that are first performed by the teacher.

The tests of IV and V are tests compilative as the labyrinth, the symmetry and the spatial organization that take into account the cognition of the students, their hand-eye coordination and the ability to adopt problem solving. In fact, to be able to get out of the labyrinth, students must cognitively anticipate the path and must be able to predict the moves necessary to be able to get to the end.

In the case of the spatial organization will give each child a squared paper with a series of commands from having to perform (two squares to the right, one square up, ect.); each command corresponds to a line that must be written on the sheet in the correct manner.

The symmetry, instead, is a test that evaluates the skills eye-hand and visio-spatial participants; in this case, asking the children to complete the drawing freehand reproducing, like a mirror, the present design.

\section{Analysis}

The results obtained by the different types of tests have been developed initially by operations of descriptive statistics, giving information of a synthesis of all the data collected. Subsequently, in order to highlight the link between skills development and chronological age of the research participants, there were transactions correlation through the correlation coefficient Kendall, who while not identifying the causeeffect relationship, we provides precise information about the link between the variables considered.

\section{RESULTS}

Table 1 indicates that most of the children at 5, 6 and 7 years are able to perform all or most of the imitative praxis. In fact, between 5-6 years there is a decrease in the average scores.

Table 1. Crossing between the age (5-6-7 years) and test praxic

\begin{tabular}{|c|c|c|c|c|c|}
\hline \multirow{2}{*}{\multicolumn{2}{|c|}{ \% within Età }} & \multicolumn{3}{|c|}{ Age } & \multirow[b]{2}{*}{ Total } \\
\hline & & 5 age & 6age & 7age & \\
\hline Imitative & 5,00 & & $5,6 \%$ & & $1,8 \%$ \\
\hline praxis & 9,00 & $4,3 \%$ & & & $1,8 \%$ \\
\hline & 10,00 & $4,3 \%$ & $16,7 \%$ & & $7,1 \%$ \\
\hline & 11,00 & $4,3 \%$ & $11,1 \%$ & & $5,4 \%$ \\
\hline & 12,00 & $8,7 \%$ & $22,2 \%$ & & $10,7 \%$ \\
\hline & 13,00 & $30,4 \%$ & $22,2 \%$ & $6,7 \%$ & $21,4 \%$ \\
\hline & 14,00 & $21,7 \%$ & $22,2 \%$ & $40,3 \%$ & $26,8 \%$ \\
\hline & 15,00 & $26,1 \%$ & $22,2 \%$ & $53,3 \%$ & $25,0 \%$ \\
\hline Total & & $100,0 \%$ & $100,0 \%$ & $100,0 \%$ & $100,0 \%$ \\
\hline
\end{tabular}


Specifically to 5 years no pupil has played less than 5 praxis, $4.3 \%$ have performed between 9 and 11 ; $30.4 \%$ have performed 13 and only $26.1 \%$ of all 15 .

In 6 years the average score decreases: $5.6 \%$ managed to imitate only five movements; $22.2 \%$ have run successfully from 12 to 14 and only $22.2 \%$ managed to realize all imitative praxis requests.

At 7 years there is an increase: all children have performed more than 12 movements and $53.3 \%$ imitated perfectly the performer completing the test.

As shown in Table 2, the first test praxic is to route freehand and is performed reaching a score uneven among children aged 8 and 9 years. The score would seem in favor of older children: 8 years the $22.2 \%$ of the students performed the test with 2-3 errors, that number tends to decrease up to $8.3 \%$ in the students of nine years; moreover, the test continues to take place with the $77.8 \%$ at the expense of children 8 years old with 0-1 errors; but 9 years the $91.7 \%$ was able to complete the maze without errors and hesitations.

Table 2. Crossing between the age (8-9 years) and tests praxic

\begin{tabular}{|c|c|c|c|c|}
\hline \multicolumn{2}{|c|}{$\%$ within Age } & \multicolumn{2}{|c|}{ Age } & \multirow[t]{2}{*}{ Total } \\
\hline & & 8 age & 9 age & \\
\hline $\begin{array}{l}\text { Praxis 1: } \\
\text { Route less } \\
\text { free }\end{array}$ & $\begin{array}{l}1,00 \\
2,00\end{array}$ & $\begin{array}{l}22,2 \% \\
77,8 \%\end{array}$ & $\begin{array}{r}8,3 \% \\
91,7 \%\end{array}$ & $\begin{array}{r}14,3 \% \\
85,7 \%\end{array}$ \\
\hline Total & & $100,0 \%$ & $100,0 \%$ & $100,0 \%$ \\
\hline $\begin{array}{l}\text { Praxis 2: } \\
\text { Symmetry }\end{array}$ & $\begin{array}{l}1,00 \\
2,00\end{array}$ & $\begin{array}{l}25,0 \% \\
75,0 \%\end{array}$ & $100 \%$ & $\begin{array}{l}14,3 \% \\
85,7 \%\end{array}$ \\
\hline Total & & $100,0 \%$ & $100,0 \%$ & $100,0 \%$ \\
\hline $\begin{array}{l}\text { Praxis 3: } \\
\text { Spatial } \\
\text { organization }\end{array}$ & $\begin{array}{l}1,00 \\
2,00\end{array}$ & $\begin{array}{l}75,0 \% \\
25,0 \%\end{array}$ & $100 \%$ & $\begin{array}{l}84,6 \% \\
15,6 \%\end{array}$ \\
\hline Total & & $100,0 \%$ & $100,0 \%$ & $100,0 \%$ \\
\hline
\end{tabular}

The second test praxis is the of the symmetry, the results of which are crossed with the age of the students. The data in Table 2 indicate that the test was held for pupils aged greater, since the $25.0 \%$ of children of 8 years old and has performed a work of symmetry with 3-4 errors, while no one to 9 years made such a large number of mistakes.

The third test praxis is to organize spatial and in this case the $75.0 \%$ of children 8 years old and have managed to perform the test with at least one error, as well as the $100.0 \%$ of pupils of 9 years. This means that all children in the fifth grade they went wrong at least once, instead the $25.0 \%$ of younger children have completed the tests of spatial organization with no errors. 


\section{DISCUSSION}

Numerous research conducted in this area have shown an inadequate, slow or even non-motor development may make it difficult to the harmonious development of the subject.

The ability or not to imitate, the ease or hindrance in performing body movements are essential to be able to have an idea, more or less complete on development praxic.

In analyzing the overall results obtained by the test of imitative praxis of I, II and III primary, you can see that the age affecting the carrying out of the activities praxic: there would be an increase in average scores with increasing the years.

The scores achieved by children of 6-7 years are almost similar, in fact, is the evidence of peers smaller (5 years) to determine important differences, since they tend to be less coordinated and give answers more inhomogeneous. In this regard, among the children of the primary and those of III there no discrepancy of almost the $30 \%$.

It 'important to note that all children, without distinction of age, were much more adept at imitating the praxis of the limbs and not those of the face probably because the first are visibly controllable and therefore correctable as they are executed; as were able to more easily perform actions usual already knew, at the expense of those who practice daily movements less or who do not practice at all.

The development of intelligence kinesic-motor, goes hand in hand with the evolutionary development of the child. Notable is the difference between a child of five years, clumsy and uncoordinated, compared to an eight / nine years. Younger students perform the praxis in an elementary way, especially those of the face that are more complicated and are not visibly controllable; older children, instead, have already developed motor skills, coordination, perception, control of body segments, balance and precision that enable it to perform exactly the required movement. (Gardner, H., 2005)

Growing up, the child, in addition to developing this, also increases the ability to mentally represent the movements. This means that the motor skills gradually increases with the symbolic capacity and everything should be between 6-7 years. (Piaget, J., 1998).

Another reasoning has to be done for the data obtained in the tests praxic of IV Elementary; tests that evaluate the movement through the troubleshooting: labyrinth, symmetry and spatial organization. The results show a slight difference in the age group that goes from eight to nine years: children of eight years have had some difficulty in more in the execution of exercise. This could be caused by the fact that the final year students have developed more motor skills, eye-hand, but also perceptive and specialization of the symbols.

At a time when the subject is aware of his own body structure, as a human being located in the world, he also manages to move, to perceive and better organize the space in which he lives.

So, in conclusion, the data collected would show how age can profoundly affect the development of motor skills and the execution systematically of the activities praxic: would result, in fact, an increase in average scores with increasing age. 


\section{CONCLUSIONS}

In conclusion, we can say that intelligence lives in the movement since the acquisition of motor skills would coincide with the growth age of the subject.

The relationship between body and mind (intelligence / cognition) that determines the timing of growth and development of the human being, makes use of the role of experiences and lived experiential learning process for the evolution of sensory-motor skills, in accordance with the scientific and cultural paradigm of embodied Cognitive Science. (Paloma Gomez, F., 2013)

At the same time, it's the same motricity that allows us to create social relationships, cognitive, emotional, with the environment and with other human beings.

Specifically, the praxis allow you to directly explore the world with whom we come in contact; allow us to express emotions, feelings and needs; are able to make the human being aware of one's body and one's body immersed among others, but always as a single unit and distinct.

Children of childhood implement movements more inhomogeneous and prove to have less coordination, but you can not deny them the ability to implement movements though not graceful; unconscious movements and incoordianti allow, however, the child to interiorize new knowledge, to discover things, to feed their knowledge and expand their cognition. Growing up with an adequate process training / education, the child should change these uncoordinated movements, in coordinated motor skills, aware and finalized (Gomez Paloma F., Agrillo F., D’Anna C., 2013).

The correct motor development, the acquisition of skills praxic and awareness of the motor pattern, allow the passage, the body as a tool, the body own through an ever more refined control of his movements; thus determining the awareness of their own physicality and the fortification of his own self (Raiola G., Scassillo I., Parisi F., Di Tore P.A., 2013).

As soon as the child grows acquires more knowledge, more skills and more skill praxic, what determines which children of 8-9 years are more coordinated, harmonious physically and conscious of the movements they perform. As soon as the child grows acquires more knowledge, more skills and more skill praxic, what determines which children of 8-9 years are more coordinated, harmonious and physically conscious of the movements they perform.

The praxis, therefore, are acquired through experience and a learning process that allows to establish an intentional relationship between motor phenomena, intellectual and emotional. (Le Boulch, J., 2006)

\section{REFERENCES}

1. Gardner, H., (1988). Formae mentis. Saggio sulla pluralità dellintelligenza. Milano: Giangiacomo Feltrinelli Editore. 2 th edition.

2. Gardner, H., (2005). Educazione e sviluppo della mente. Intelligenze multiple e apprendimento. Trento: Centro Studi Erickson.

3. Gomez, F. (2013). Embodied Cognitive Science. Atti incarnati della didattica. Roma: Edizioni Nuova Cultura. 
4. Gomez, F., Agrillo, F., \& D'Anna, C. (2013). Parent's perception about motor-sport activity in Italian primary school. Journal of Human Sport And Exercise, 8, pp.165-179.

5. Gomez, F., Rio, L., \& D’Anna, C., (2014) Physical self-efficacy in women's artistic gymnastic between recreational and competitive level, Journal of Human Sport And Exercise, 9, pp.341-347

6. Le Boulch, J. (2006). Verso una scienza del movimento umano. Roma: Armando Editore.

7. Piaget, J., (1998). La phychologe de l'intelligence. Armound Colin Publisher, 7 th edition. Firenze: Giunti Editore.

8. Raiola, G., Scassillo, I., Parisi F., \& Di Tore, P.A. (2013) Motor imagery as a tool to enhance the didactics in physical education and artistic gymnastic, Journal of Human Sport and Exercise, 8(2), pp.93-97

9. Raiola, G., Tafuri, D., \& Gomez, F., (2014). Physical activity and sport skills and its relation to mind theory on motor control, Sport Science 7(1), pp.52-56

10. Altavilla, G., Tafuri, D., \& Raiola, G. (2014) Some aspects on teaching and learning by physical activity Sport Science 7 (1), pp.7-9 